\title{
Research Organisations in British Shipbuilding and Large Marine Engine Manufacture: 1945-1959 (Part II)
}

\section{Hugh Murphy}

Cet article fait suite à la première partie, qui traitait de la période 1900 à 1944. Ici, l'auteur étudie l'impact de la British Ship Research Association, de la Parsons Marine Turbine Research and Development Association et, de façon tangentielle, d'un groupe de conseil en recherche privé, le Yarrow Admiralty Research Department (Y-ARD), une filiale de Yarrow Shipbuilders établie dans le district Scotstoun de la rivière Upper Clyde, et le National Physical Laboratory (NPL). Il traite également de William Doxford \& Sons, avant d'évaluer l'impact individuel et collectif de ces sociétés jusqu'en 1959, ainsi que la situation générale de la construction navale britannique et la fabrication de gros moteurs maritimes.

This article follows on directly from Part 1 covering the period 1900-1944, published in the last issue. Here I examine the impact of the British Ship Research Association (BSRA) and Parsons Marine Turbine Research and Development Association (PAMETRADA). Tangentially I review one private research consultancy cluster, the Yarrow Admiralty Research Department (YARD) an offshoot of Yarrow Shipbuilders, Scotstoun, on the Upper Clyde, and the National Physical Laboratory (NPL). I also consider Wm Doxford \& Sons, before assessing their individual and collective impact up to 1959, and the general situation in British shipbuilding and large marine engine manufacture.

The Northern Mariner / Le marin du nord, XXX, No. 2 (Summer 2020), 133-154 


\section{Parsons Marine Turbine Research and Development Association (PAMETRADA)}

Beginning with just seven employees in January 1945 when the designs of its first turbine were drawn in two large rooms above a Wallsend public house, the Coach and Horses, whilst its future premises were under construction, the total rose to seventy in 1947, and by 1952 PAMETRADA employed 270 staff. ${ }^{1}$ A major part of its overall remit was to carry out shore based tests on complete sets of turbine machinery including gearing, boilers and auxiliaries. The Admiralty undertook to use the facilities for their tests, but PAMETRADA was free to conduct its own tests on merchant ship turbines on behalf of its member firms. Second, PAMETRADA would supply basic machinery designs to the requirements of its member firms and their customers and, third, to improve these designs by a program of research and development of turbine machinery to include the development of the gas turbine as well as the steam turbine. ${ }^{2}$

C.A. Parsons, who had sixteen UK licensees, initially supplied PAMETRADA with a 3,500 shp turbine for research purposes and also an experimental gas turbine. ${ }^{3}$ From its establishment in May 1944 as a limited company without share capital, hence no profit motive, PAMETRADA had nineteen member firms, fourteen of which combined shipbuilding and marine engine building, and five who were specialist engine builders. ${ }^{4}$

PAMETRADA was mostly financed by its member firms but had DSIR support on basically the same terms as BSRA. There was no provision for Shipbuilding Conference support: but the conference did give financial support to PAMETRADA at various stages in the 1950s. Membership excluded the much better capitalised land turbine firms such as English Electric, British Thomson-

1 J.F. Clarke, Building Ships on the North East Coast, part 2, (Whitley Bay: The Bewick Press, 1997), 423. There is a short administrative history of PAMETRADA, see, R.F. Darling, 40 Years of Progress. A History of the Wallsend Research Station, 1945-1985, (London: British Maritime Technology Ltd, 1985). Darling joined PAMETRADA in 1945 and rose to become chief engineer (research), and later assistant director (administration), BSRA.

2 Darling, 40 Years of Progress, 10-11.

3 C.A. Parsons are credited with the first industrial gas turbine to run in the United Kingdom, a $500 \mathrm{hp}$ experimental machine first run in 1945. See, A.T. Bowden and J.L. Jefferson, "The design and operation of the Parsons Experimental Gas Turbine," Proceedings of the Institute of Mechanical Engineers (1948), 454-474. By July 1950, testing of the 3,500 shp gas turbine at PAMETRADA could be carried out up to a power of $60,000 \mathrm{shp}$ per shaft. The dynamometer used for this purpose was the largest in the world at that point, and the speed, at the maximum brake rating was $160 \mathrm{rpm}$. See "Marine Gas Turbine Research. The PAMETRADA 3,500shp Plant," The Motor Ship, (July 1950).

4 These were, Barclay Curle, John Brown, Denny Bros, Fairfield, J. G. Kincaid, David Rowan, Alexander Stephen, Scott's Shipbuilding and Engineering, and Yarrow all on Clydeside; Harland and Wolff at Belfast and Govan on the Clyde, Cammell Laird at Birkenhead, Vickers Armstrong at Barrow and on Tyneside, Charles Parsons, Hawthorn Leslie, Wallsend Slipway on Tyneside, Central Marine, and Richardson, Westgarth both at West Hartlepool, J. Samuel White at Cowes and J.L. Thornycroft at Southampton. 
Houston, and Metropolitan Vickers (both Thomson-Houston and Met Vickers merged in 1928 under the holding company, Associated Electrical Industries, (AEI) but continued as separate companies) in whom the Admiralty was interested in bringing to bear their capital, research facilities and land turbine experience to marine turbine design. Given this, PAMETRADA had a clear imperative to outperform their land competitors in turbine design. ${ }^{5}$

That this would in fact occur did not necessarily follow. Of the nineteen member firms, fifteen were members of the warship group within the Shipbuilding Conference who built turbines for the Royal Navy mainly under licence to Parsons designs. These designs had to be per se competitive against other competing designs and, given the importance of Admiralty contracts to the larger and medium sized shipbuilding firms, there was nothing to stop, with suitable Admiralty encouragement, member firms building turbines for the Admiralty under licence from a land turbine firm. In part, also, PAMETRADA was an attempt to harness and develop British technical expertise and to answer a long-held criticism of the marine engine building industry that it was too dependent on foreign licences.

By 12 August 1946, PAMETRADA's designers had finally vacated their office above the Coach and Horses and moved to a newly built two storey office block at its future research station on a thirty acre site at Wallsend, Davy Bank, on Tyneside. ${ }^{6}$ Staffed partly by personnel from member firms who seconded marine engineers, its functions from the outset were limited to producing basic design information on the manufacture elsewhere of sets of steam turbine machinery. It was not a trading organization and had no direct connexion with any works building steam turbines. Income, setting aside the Department of Scientific and Industrial Research (DSIR) grant, was derived from levies on member firms on a graduated scale per output; and from royalties on turbines built to its designs; with member firms paying commensurately less, and lastly through overseas licensees. Given that the largest firms in the industry were mixed naval and mercantile builders, PAMETRADA ideally should have been well placed to operate in both markets. In 1947, the land turbine firm, English Electric applied to join, but were turned down as they were

\footnotetext{
5 English Electric was under the control of the American Westinghouse Corporation. Both Metropolitan Vickers (Trafford Park, Manchester) and British Thomson-Houston (Rugby, Warwickshire) were from 1928 subsidiaries of a holding company, Associated Electrical Industries formed in 1926. AEI was under the control of the American General Electric Company. Metropolitan Vickers and British Thomson-Houston both remained publicly quoted firms and had an intense rivalry. AEI was acquired by GEC in 1967 and in the following year GEC merged with English Electric. For a discussion of the land turbine firms and eventual consolidation of that sector, see Robert Jones and Oliver Marriot, Anatomy of a Merger: A History of GEC, AEI and English Electric (London: Jonathan Cape, 1970).

6 Darling, 40 Years of Progress, 23, points out that the office block was the only completed building at August 1946, and that work was progressing on a boiler house, test bed and a research house. A laboratory block was completed by the end of 1951 , by which stage a third storey had been added to the original office block. A turbo combustion building had been erected, and by 1954 a second and larger office block and large workshop were operational.
} 
not a "marine" firm. ${ }^{7}$ At the time and later this would prove to be a grave error of judgement.

\section{The general situation in large marine engine-building}

Post-1945, British shipowners, the main determinant of demand, had a wide range of marine propulsion machinery available to them, and for each basic design several alternatives existed. The marine triple expansion engine, available either with saturated or superheated steam, with the additional options of a re-heat phase or an exhaust turbine to enhance fuel economy was already being superseded by marine diesels, mostly of continental design of steadily increasing power and greater fuel efficiency. For larger ships, the marine steam turbine with single or double reduction gearing remained dominant, although American practice in a country which had never really accepted the motor ship, ${ }^{8}$ had increasingly relied upon electric transmission with the steam turbine as the prime mover, and the gas turbine, of huge potential for warships, was already on the horizon. The philosophy that had led to machinery designs for a post-war Royal Navy with smaller ships: "necessitated a drastic reduction in machinery, and fuel weight and space in face of increasing demands by weapons and their equipment for weight and space, and for better standards of accommodation. ${ }^{" 9}$ Moreover, in a nuclear age, the need for warships to be at continuous short notice for sea, and to remain at sea for some time unsupported by base, meant that turbine machinery had to be rugged and give long range capability. ${ }^{10}$

On the naval side, most Royal Navy warships had long been propelled by steam turbines and these had been exclusively supplied by British shipbuilding and marine engine-building establishments. For shipbuilding firms, it had long been policy to build both the hull and the prime mover in the same establishment, a factor linked with a similar policy for mercantile demand that explains why most of the large and medium-sized firms owned engine works in or near their shipyards. For the larger builders, hull and main engine building gave them more control over the finished product and allowed overhead costs to be more evenly spread. Undertaking both naval and mercantile work in the same establishment offered some protection against the vagaries of the trade cycle and aided the retention of skilled personnel. It also allowed shipbuilders to keep control of delivery dates for installing engines and familiarise their labour force with installation in diverse

\footnotetext{
7 Department of Scientific and Industrial Research Report (London: HMSO, 1960), para., 37, hereafter, DSIR. English Electric had in fact built marine turbines during the Second World War.

8 One important American exception was the only Doxford USA licensee, Sun Shipbuilding and Dry Dock Company of Chester Pennsylvania who produced a large series of Sun-Doxford driven tankers.

9 Technical Liaison Committee, Admiralty and Warship builders, first meeting 14 March 1958. Quote from deputy engineer-in-chief, Rear Admiral W.F.B. Lane, University of Glasgow Business Records Archives, Thurso Street Glasgow, GD319/12/10/52.

10 Ibid
} 
ships. With engine works mostly adjacent to shipyards, transport costs were also minimised.

At first glance, there was little overlap between the two research associations, however, in some respects their research activities, although seemingly divergent, were in terms of prime movers complimentary. BSRA went on to conduct considerable research on marine diesel and gas turbine propulsion, whilst PAMETRADA could use the experience gained on providing the designs for five of the eight Daring class destroyers built for the Royal Navy to aid the development of competitive turbine designs for merchant shipping. Sadly, for the prospects of PAMETRADA in the naval sphere, the initial success in securing the bulk of the Daring turbine design contracts was not followed up in terms of future contracts as it soon became clear that the Admiralty were ever more determined to involve better capitalised land turbine firms.

\section{The Daring Class Destroyer program}

The first turbine to run on the PAMETRADA test bed at Wallsend was for the SS Duquesa in August 1948. ${ }^{11}$ This gave the team experience which led to fullscale trials in January 1949 commissioned by the Admiralty on complete sets of machineries, including boilers and auxiliaries for its Daring class destroyer program. Eight of these warships, the last in the Royal Navy with guns as their main armament, were to be built, and the opportunity had been taken of employing three different designs of machinery of the same power to obtain comparisons of their performance.

Daring 1 was designed by C.A. Parsons and PAMETRADA. ${ }^{12}$ The prototype, manufactured by Wallsend Slipway was later fitted in HMS Daring, and in four other destroyers of the class. ${ }^{13}$ Daring II was designed by the land turbine firm, British Thomson-Houston and PAMETRADA. ${ }^{14}$ Manufactured by John Brown at Clydebank, it was later fitted in HMS

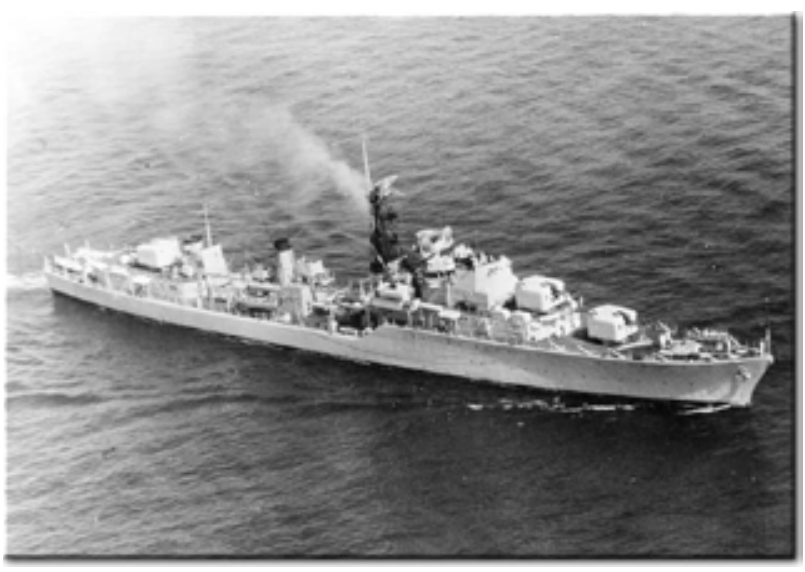

HMS Daring (D05) Wikimedia

11 This section is heavily reliant on Darling, 40 Years of Progress, 31-32.

12 An impulse reaction turbine H.P. Turbine, reaction L.P. turbine and double reduction locked-train gearing.

13 HM Ships Delight, Duchess, Dainty and Defender.

14 An all-impulse H.P. turbine. 
Diamond. Daring III's turbines were designed and manufactured by English Electric and the gearing by Fairfield Shipbuilding and Engineering at Govan. ${ }^{15}$ The prototype was fitted in HMS Decoy and similar machinery, but with different gearing, in HMS Diana.

All three designs were of 30,000 max horsepower at a propeller speed of 300 $\mathrm{rpm}$, with steam conditions of $550 \mathrm{psi} / 825^{\circ} \mathrm{Fahrenheit}$. Daring III used higher blade speeds and stresses and was regarded as a "Limit" design; however, the boilers and auxiliaries were the same for all three designs. Daring I was tested for the first time on 31 January 1949 and the last test run on Daring III occurred on 6 April 1951. As Darling later noted, the most severe of problems was that of instrumentation providing accuracy and reliability of measurement over the course of the three test runs of machinery. In the event, the three sets of Daring machineries were deemed fit for purpose, with no one clearly superior, however, the Daring III machinery was appreciably lighter than either of the other two. ${ }^{16}$

Although PAMETRADA had provided the designs for five of the eight Daring Class destroyers, this proved to be its heyday in the warship design field as the Admiralty were clearly set on a future course of involving land turbine firms, particularly English Electric. With PAMETRADA now basically consigned to testing rather than designing naval turbine machinery, but continuing in the merchant ship field, one shipbuilding and land boiler firm, Yarrow, a builder of destroyers and later frigates for the Royal Navy and a member of the Warship Group of private shipbuilders, attempted to cement its links with the Admiralty. In this, self-interest was undoubtedly the motivating factor rather than any altruistic industry-wide motive.

\section{Yarrow Admiralty Research Department (YARD)}

YARD was an attempt to improve research on naval propulsion machinery following experience in the Second World War. In 1946, the Admiralty through its Engineer-in-Chief's department hedging its bets, invited Yarrow to cooperate with the English Electric Company to investigate the effects on turbine machinery of increases in steam temperature and pressure. ${ }^{17}$ The intention was that Yarrow would supply ship and boiler design knowhow, and English Electric with steam turbine experience. ${ }^{18} \mathrm{~A}$ small team from both companies undertook a worldwide review of modern steam land and marine turbine practice at a mansion in Rugby, Warwickshire. In January 1948, the team relocated to Yarrow's shipyard

\footnotetext{
15 An all-impulse H.P. and L.P turbines and double reduction locked-train gearing.

Darling, 40 Years of Progress. 32.

17 Records regarding this period are held at the National Archives Kew, London in the ADM 317 classification. See also, Alastair Borthwick, Yarrows: The First Hundred Years, 1865-1965, (Glasgow: Yarrow and Co., 1965), 82-88.

18 Jan Neumann, "Development of Naval Machinery and YARD Ltd," The Institute of Engineers and Shipbuilders in Scotland, Transactions 137 (1993-94), 2.
} 
at Scotstoun on the upper Clyde. ${ }^{19}$ They began work on two naval machinery installations, one based on best practice and the other experimental; and thereafter produced recommendations for the improvement of turbine (steam and gas) propulsion machinery design. ${ }^{20}$

In 1949, work began on the design of new class of anti-submarine frigate, and English Electric staff left the team to allow them to bid for main marine turbine work on which the team had been employed. Yarrow, to preserve a modicum of impartiality, contemporaneously volunteered not to submit boiler proposals to their own design for any Royal Navy machinery installations, which the team had assessed. ${ }^{21}$ Thereafter, YARD continued as a profit-making design and consultancy organisation to provide the Admiralty with technical advice on naval turbines in tandem with taking responsibility for the construction of prototype machinery. It operated as a separate department of Yarrow and Co., with its general manager reporting to Yarrow's deputy managing director. ${ }^{22}$

In late 1949, the Admiralty, as an extension of a twin-screw anti-submarine frigate design contract, (with PAMETRADA, English Electric and Metropolitan Vickers originally invited to tender designs), ordered the design and construction of a shaft set of the chosen machinery for shore testing, this became known as the Y-100 machinery, with English Electric, whose design incorporated a special feature of a cruising turbine automatically clutched "in" and "out" to suit cruising powers being given the contract. ${ }^{23}$ It was shore tested at PAMETRADA's Wallsend headquarters, and subsequently adopted in the Whitby class frigates. However, the cruising turbine clutch (declared as fully developed by the Admiralty) was later found to be unsatisfactory in service and in future ships employing this machinery it was eliminated entirely. ${ }^{24}$

The Admiralty considered the PAMETRADA design unacceptable for three reasons: a lack of prior experience of higher steam conditions; that they only designed blade paths, and that other firms had exchange of information with US firms designing and manufacturing turbines for the US Navy. Subsequently, PAMETRADA were offered the opportunity of producing an alternative design to the Y100, but in March 1951 they were told that there was no point in pursuing

\footnotetext{
19 Borthwick, Yarrows, 82.

20 Neumann, "Development of Naval Machinery," 2.

21 Borthwick, Yarrows, 83.

22 Neumann, "Development of Naval Machinery," 2. Originally, there were two joint managers of YARD, but soon after its inception, a single manager, Eric Dott Hobson was appointed. Dott Hobson had served in the Royal Navy's submarine service as a lieutenant during the Great War, and was invalided out of the service in 1919, and spent many years thereafter at a firm of pump manufacturers as an Admiralty Liaison and Trials Executive. He served fifteen years as YARD's general manager.

23 15,000 shp Turbines manufactured under licence from English Electric and gearing by Vickers Armstrong. The Royal Canadian Navy used these Y-100 turbines for their St Laurent and subsequent classes, and Yarrow also used machinery of this type for frigates built for the Australian, New Zealand, South African and Indian Navies.

24 Shipbuilding Inquiry Committee (SIC) Evidence. Memorandum on Pametrada, 16 July 1965, The National Archives, Kew, London (TNA), BT 186/20.
} 
this, as nine British firms (all PAMETRADA members) were coping adequately with English Electric's design, and it was hoped that another five firms would do likewise. ${ }^{25}$ Contemporaneously, the Admiralty requested YARD to formulate an installation design for a smaller single-screw frigate, using one shaft set of Y-100 main propelling machinery and appropriate boilers and auxiliaries; this was awarded the nomenclature of Y-101 and was later adopted for the Blackwood class of frigates. ${ }^{26}$

In 1950, the Admiralty again requested that YARD prepare specifications and guidance drawings and the detailed design and manufacture of an experimental $30,000 \mathrm{shp}$ set of turbine machinery with the codename, YEAD $1^{27}$ for erection and shore testing again at PAMETRADA's Wallsend facility. This contract necessitated a great deal of metallurgical development and testing of steels to withstand high steam pressures and stresses, and, inter alia, research into automatic controls capable of maintaining full control of machinery during attack with nuclear weapons. ${ }^{28}$ Unsurprisingly, this took some years of research and development.

Beginning with the erection of machinery in early 1954, the last trial of the YEAD 1 machinery at PAMETRADA at Wallsend occurred on 28 February 1958. A fair amount of this time was taken up in awaiting components and in rectification of minor defects. In all the process generated 243 internal reports and 100 interim reports, in addition to extensive final reports. ${ }^{29}$ However, although it was never installed in a ship, it was significant in the future development of marine turbines.

Subsequently, the Admiralty offered to examine a corresponding design from PAMETRADA as a "paper exercise," but there was really no question of accepting any alternative to the 30,000 shp design by English Electric Company. ${ }^{30}$ This extended program did however provide PAMETRADA with much needed income and further experience in naval steam turbine machinery testing, and it is likely that it also enhanced its mercantile steam turbine research.

Contemporaneously with the shore testing trials; the Admiralty had switched its interest to the development of the gas turbine to warship propulsion. Largely because of this, the Admiralty informed PAMETRADA, well before the end of the YEAD 1 shore testing that it would not commission any further tests of this type. ${ }^{31}$

Earlier in 1952, the Admiralty had intimated to YARD its intention to employ gas turbine propulsion in larger warships. Accordingly, YARD undertook a design study of a combined steam turbine gas turbine boost installation (COSAG) using AEI G-type gas turbines. Research pointed to the possibility of not only using the gas turbine as an ahead boost unit, but also as a source of manoeuvring power, ahead

\footnotetext{
25 Ibid.

26 Borthwick, Yarrows, 84.

27 Yarrow English Electric Design (YEAD) Main turbines manufactured by English Electric and gearing by Vickers-Armstrong.

28 Borthwick, Yarrows, 84.

29 Darling, Forty Years of Progress, 33.

30 Memorandum from Pametrada to SIC, 16 July 1965, TNA BT 186/20.

31 Darling, Forty Years of Progress, 33.
} 
or astern, with the steam turbine out of use. Subsequently, in 1954, the Admiralty ordered the design, manufacture and shore testing of a unit comprising two AEI G6 Gas turbines and main gearing, with the appellation Y-102. Although YARD was instructed to provide specification and guidance drawing for the new County class guided missile destroyer program, an opportunity arose to propose this COSAG machinery for a smaller general purpose single screw frigate program. This was successful and Yarrow subsequently received an order to construct the first of the Tribal class of frigates, HMS Ashanti. It was in this first of class that the prototype trials of the COSAG machinery was carried out by Admiralty, YARD and AEI personnel. During Ashanti's early sea trials, the gas turbine was started up from cold in an emergency and drove the ship within seven minutes. ${ }^{32}$

Thereafter, Yarrows rose to become the premier builder of frigates for the Royal Navy and YARD's future was all but guaranteed. By 1960, in stark contrast to Doxford, YARD employed sixty qualified engineers and scientists. ${ }^{33}$ YARD later survived Yarrow's ill-fated membership of the Upper Clyde Shipbuilders consortium in 1968, becoming an entity in its own right in 1969 as a wholly owned subsidiary of Yarrow. It was subsequently acquired by a consortium of British Aerospace and SEMA, a French firm in 1991 and in 1998 reverted to BAe Systems who bought out SEMAs 50 percent stake. ${ }^{34}$

\section{Wm Doxford during the 1950s}

In 1946, Doxford took over a local marine engineering firm, John Dickinson and Sons at Palmers Hill, north of the River Wear and nearer to the North Sea. The purchase included a $650 \mathrm{ft}$ long fitting out quay, and the engine works was used for testing, research and development, including instrumentation work for BSRA. Doxford's emphasis on war production and backlog meant that research was not undertaken formally until 1947, when under great pressure from licensees, including a threat from Hawthorn Leslie's Sir Philip Johnson for licensees and others to set up a diesel equivalent of PAMETRADA, Doxford's managing director and deputy chairman, John Ramsay Gebbie (1889-1968) and engineering general manager, William Hamilton Purdie (1888-1971) established an R \& D department at Palmers Hill under Percy Jackson (1897-1984) as Chief Development Engineer. Jackson's experience was in medium not slow speed diesels, ${ }^{35}$ with Ernest R.

\footnotetext{
32 Borthwick, Yarrows, 85.

33 DSIR Report, 1960, para. 42.

34 The YARD project reports and specifications from the Admiralty and Ministry of Defence (Navy) are held in the ADM 317 classification at The National Archives, Kew.

35 Before joining Doxford, Jackson was technical director at Mirrlees, Bickerton and Day, Hazel Grove, nr Stockport, Cheshire. As E.P. Crowdy (Hawthorn Leslie Engineers) later noted, Jackson was familiar with four-stroke, poppet valve, single trunk piston medium speed diesel engines but not with large slow speed two-stroke opposed piston marine diesels, whose development he was entrusted with. Crowdy caustically pointed out that there were no similarities whatsoever, save that both engines worked on the diesel cycle. See A. Storey and E.P. Crowdy, "The Final Years of Doxford," Marine Engineering and the North East Coast. An historical symposium held at the
} 
Groschel as chief research engineer, the latter seconded from BSRA on a three-year contract. ${ }^{36}$ The R \& D mandate was: "Doxford will accept the task of undertaking research and development to ensure that a geared diesel engine equal to any other will in future be available to Doxford Licensees and to British marine engineering in general." ${ }^{37}$ However, the Doxford R \& D department at that stage comprised only two people! And it never reached more than five..$^{38}$

The principal aims of research were to improve the rating of its engines; reduce space required, reduce weight per horsepower, investigate pressure charging, reduce fuel consumption, and survey the question of diesel engine design in general. This was at least progressive but would certainly require extra investment. Doxford's two-man research department contrasted greatly with two land turbine firms increasingly looking to develop marine propulsion turbine sets, Metropolitan Vickers and British Thomson Houston, whose employment numbers in R\&D in 1950 and 1951 accounted for 600 and 320 people respectively; most of whom were undoubtedly employed on land not marine turbine research, but could switch what had been learned on one to the other. ${ }^{39}$

The series of technical meetings with Doxford licensees instituted in May 1948 continued intermittently and by the fourth meeting in June 1949, representatives of Australian, Italian and Swedish licensees attended for the first time. ${ }^{40}$ There, Doxford stated that supercharging was a long-term policy, ${ }^{41}$ and the licensees

Museum of Science and Engineering, Newcastle upon Tyne, 26 November 1988, in Proceedings of the North East Coast Institution of Engineers and Shipbuilders, (NECIES) 105: 2 (1989), 66-67.

36 Clarke, Shipbuilding on the North East Coast, 405. Groschel was paid $£ 1,000$ per annum to be responsible for the Research Department and to report to Jackson. Clarke only mentions Groschel in passing. Further research indicates that he was Czech born in c.1911 and migrated to England to escape the Second World War. After a period working at BSRA, US Patent applications indicate that he worked for the Lincolnshire engineers, Ruston and Hornsby Ltd during the 1960s. Ruston and Hornsby were taken over by English Electric in 1966 and subsumed into GEC in 1968.

37 The $32^{\text {nd }}$ Andrew Laing Lecture, P. Jackson, "Two Decades of Research and Development on the Doxford Engine," Trans NECIES 80: 11 (November 1963), 1.

38 Minutes of Doxford Licensees Meetings, $1^{\text {st }}$ meeting, Doxford Pallion Office, 11-12 May 1948, Ballast Trust, Walkinshaw Street, Johnstone, Renfrewshire, Scotland, uncatalogued Doxford papers.

39 D.E.H. Edgerton, "Science and Technology in British Industry," Business History 29: 4, (1987), 100. Edgerton did not make this comparison. He notes, at p.102, that AEI only opened a fundamental research laboratory at Aldermaston in 1947, away from its principal operating sites and close to London, which employed forty-eight graduates.

40 Minutes of Doxford Licensees Meetings, 3rd meeting, Doxford Pallion Office, 14 June 1949, W.A. Mappin Commonwealth of Australia, Mr de Vito, Ansaldo \& Co., and Mr Lindh, Eriksberg Mek Verkstad, Ballast Trust.

${ }^{41}$ The term "supercharging" seems to have been widely used to include turbocharging, when all forced induction devices were classed as superchargers. A turbo-charged engine can produce significantly more power than a naturally aspirated engine of the same configuration, as having more air in the cylinders allows more fuel to be burned and thus more power to be produced. A supercharger is powered mechanically by the engine's crankshaft. In supercharging, a greater weight of air is forced into the cylinder before compression begins, while a turbocharger is powered by the engine exhaust, and does not require mechanical power. Turbo-charging can improve the fuel economy of diesel engines by recovering waste heat from the exhaust, increasing the excess air 
agreed that the possibility of supercharging the Doxford engine rather than building bigger engines should be considered and tested. By the tenth meeting in April 1952, Sir Philip Johnson, on behalf of the licensees, stated that they were very impressed with the performance of a supercharged Doxford engine under test conditions, which promised a 50 percent increase in power. Johnson opined that the development of a supercharged engine opened an entirely new field for the marine diesel engine in that it would be available for higher powers, and would thus be an alternative to the steam turbine, which to then, had been the only means of propulsion for single screw ships of more than about 9,000 bhp. Moreover, where weight and space considerations were important, supercharged engines offered a solution, and a reduction in cost per horsepower, as a 50 percent increase in power was being obtained with an increase in cost of only 10 percent. Accordingly, the licensees agreed that Doxford should prioritise the development of a supercharged engine. ${ }^{42}$

It followed that development was just that and would necessarily take time if full efficiency in supercharging was to be obtained. Moreover, Doxford's continental competitors were hardly likely to stand still, and so it proved as Burmeister \& Wain had by July 1952 published material on supercharging its range of marine slow speed diesels. Up to this juncture, Doxford had issued twelve research reports to its licensees, and W.H. Purdie was not in day-to-activity but remained a member of the Board. ${ }^{43}$ Earlier in 1951, the largest British-built Doxford marine diesel slow speed engine built under licence, entered service on the 19,000dwt tanker, Polarbris.4

From 1948 motor ship tonnage launched in UK shipyards finally surpassed steam ships and never looked back. The portents for Doxford had rarely looked better, and by 1952 it had over $2 \mathrm{~m}$ bhp on order in the UK and held at its peak 27 percent of the world market for slow speed direct drive diesel engines. ${ }^{45}$ By 1953 there had been a change in personnel at Doxford when W.H. Purdie retired, and from July was replaced by Arthur Storey (1906-1994) ${ }^{46}$ as director and general manager of the engine works. To increase production Storey supervised construction of new

factor, and increasing the ratio of engine output to friction losses. However, a two-stroke engine does not have a discrete exhaust and intake stroke and thus is incapable of self-aspiration. Therefore, two-stroke engines were fitted with a blower to charge the cylinders with air and assist in dispersing exhaust gases, a process referred to as "scavenging."

42 Minutes of Doxford Licensees Meetings, $1^{\text {th }}$ Meeting, Doxford Pallion Offices, 1 April 1952, Ballast Trust.

43 Minutes of Doxford Licensees Meetings, $11^{\text {th }}$ Meeting, Doxford Pallion Offices, 2 July 1952, Ballast Trust.

44 The Motor Ship, July 1951, built and engined by Barclay Curle for Polaris A/S - Melsom \& Melsom, Larvik, Norway, of six-cylinders and 8,000 to 8,500 bhp.

45 Storey and Crowdy, "The Final Years of Doxford," 66.

46 Interview with Arthur Storey, 15 May 1991, British Shipbuilding History Project, Centre for Business History, University of Glasgow. Born in Wallsend, Tyneside, Storey left school at 14 yearsold and was later apprenticed to North Eastern Marine, where he spent thirty-two years and rose in the company to become a director, before joining Doxford. 
machine and pattern shops, which were operational early in 1954. However, the competition had not stood still and by the end of 1953, there were five Burmeister \&Wain turbocharged two stroke engines in service and fifty-nine on order of $550,000 \mathrm{bhp}$, and of these nineteen had an output of more than 10,000 bhp. As the trade magazine, The Motor Ship pointed out: "The progress of the turbo-charged two-stroke engine, has, therefore, been extremely rapid and confirms the belief that within five years no two stroke Diesel engine will be constructed other than the turbocharged type. Fourteen of the units are to be installed in tankers from 29,500 to 34,00 tons, the largest being nine-cylinder engines, $740 \mathrm{~mm}$ bore developing 11,500 bhp (continuous service) at $115 \mathrm{rpm} .{ }^{.47}$

Not only did this confirm the rise in power output through turbocharging, it also confirmed its rationale, as ships, particularly oil tankers, had rapidly increased in size post-1950 and in average speed. ${ }^{48}$ Doxford was obviously behind the curve, it had hitherto operated on the basis that its power range was right for the ships constructed. This was essentially true in that Doxford itself could not build very large ships, but its competitors certainly could. On 29 December 1951, Doxford completed it largest ship to that date, Charlton Venus, an oil tanker of 16,800 dwt.

Indeed, it was not until December 1954 that an experimental three-cylinder supercharged engine (with piston scavenging pumps) was installed for test purposes on the tanker British Escort,$^{49}$ and after three months it was running satisfactorily, with increased power of 30 percent over the normal rating and a moderate increase in maximum cylinder pressure. ${ }^{50}$ However, the engine was later removed and used for test purposes at Doxford.

Experimentation had nevertheless continued, and Doxford's single cylinder $650 \mathrm{~mm}$ bore engine had been modified to prevent corrosion of the crankshaft by incorporating a circular diaphragm plate and gland between the lower piston and the crankcase,$^{51}$ the first diaphragm engine was fitted into the oil tanker Sheaf Holme in May 1955. Earlier in 1952, in response to demand for higher powered engines, a large normally aspirated (not supercharged) six-cylinder $750 \mathrm{~mm}$ bore engine running at $110 \mathrm{rpm}$ to deliver up to $8,850 \mathrm{bhp}$ had been introduced, of which fourteen were built. Its widespread acceptance by shipowners was bedevilled by a series of crankshaft failures, five of which occurred in engines in the first six

\footnotetext{
47 The Motor Ship, December 1953.

48 The Motor Ship, September 1954. A super tanker of this era was considered to be over 24,000 dwt and at September 1954 there were around 165 of these vessels in service with another 150 on order. Before the Second World War the average speed of the world tanker fleet was 11 knots. Ships on order at September 1954 had an average speed of 15.5 knots.

49 Formerly Empire MacCabe, completed by Swan Hunter \& Wigham Richardson in November 1943 and sold in 1946 to the British Tanker Co., Ltd and renamed British Escort.

50 Clarke, Building Ships on the Northeast Coast, 406-7.

51 In September 1954, Doxford introduced a circular diaphragm plate and gland arrangement, isolating each cylinder from the crankcase and allowing access to the piston rod gland. This was done together with the cooling of the lower piston by oil instead of distilled water. The diaphragm prevented the products of combustion of the heavy fuels being introduced and avoided corrosion of the crankshaft. For this engine, see, The Motor Ship, October 1954 and February 1955.
} 
months of $1955 .^{52}$

At this juncture, turbo-charged continental designs were now available to licensees up to $15,00 \mathrm{bhp}$, and in some cases, up to $17,500 \mathrm{bhp}$. These main engines compared favourably with geared turbine machinery, especially in fuel consumption and size and weight (including bunkers), opening the possibility of more main diesel engines entering service in large single screw cargo liners and tankers. ${ }^{53}$ This market was not serviced by Doxford.

Earlier, during the 1953-4 period J. Ramsay Gebbie refused licence applications from engine builders in West Germany, Japan, Poland and Yugoslavia. This was incredibly short sighted, especially in the case of Japan, which in 1956, supplanted Great Britain, and became the world's largest shipbuilder and kept that title until the end of the century A motive to protect existing licensees was undoubtedly germane to Gebbie's decision. However, over 50 percent of British built large motorships were engined with Doxford engines during the 1950s, and overseas builders would have extended market share, and provided extra investment monies to further enhance Doxford engine research and development.

Doxford's hands-off chairman, Dr Edward Philip Andreae had overseen, with Gebbie in daily control, the modernisation of the shipyard, including new welding sheds, which was underway in 1951. By 1953 this had cost £1m and work including extension of the engine works continued until 1957.54 Andreae restructured the firm in 1956 into a holding company retaining the original name, and two subsidiary companies covering shipbuilding and engineering. Although the subsidiary companies were supposedly equal, shipbuilding took priority as did its machinery requirements. This heavily impacted upon research and development on main engines as competitors built to higher powers.

Doxford's engineering director, Arthur Storey realised that it needed to develop its R \& D and extend its engine building capacity to retain and expand market share. However, Andreae's successor as chairman, Gebbie, pointedly refused in 1957 to allocate agreed funding for new engine works facilities reducing it by over half. This despite the engine works being more profitable than the shipyard, a situation mirrored in other shipyards around the country. As Storey later noted: Doxford could only build six ships per annum and with contemporary market prices could only make around $£ 350,000$ maximum in profit. In 1957 alone, Doxford's engine works made around $£ 1.6 \mathrm{~m}$ profit on eighteen engines. Gebbie's insouciance led to the resignation in 1958 of Storey who left to take up a post at Vickers at Barrow, and who remained critical of Gebbie for the rest of his life. ${ }^{55}$ Gebbie also vetoed Storey's plans to extend the technical office accommodation and thus match the

\footnotetext{
52 Clarke, Building Ships on the Northeast Coast, 410-11

53 The Motor Ship, April 1955.

54 Richardson, William Doxford \& Sons Ltd., 197.

55 A. Slaven and H. Murphy, Crossing the Bar. An Oral History of the British Shipbuilding, Ship Repairing and Marine Engine Building Industries in the Age of Decline, 1956-1990 (Liverpool: Liverpool University Press, Research in Maritime History 51, 2013), 91, Arthur Storey interview.
} 
technical support by Sulzer and MAN. ${ }^{56}$

Only in February 1957 was the first ship completed with a Scott-Doxford turbocharged engine with three lever-driven scavenge pumps, the first with turbo-blowers in 1958, and later that year the first without scavenge pumps. ${ }^{57}$ Robert Atkinson (1916-2015) replaced Storey as Doxford's Managing Director (Engineering). Atkinson would have an equally bad relationship with Gebbie.

\section{BSRA and PAMETRADA in the 1950s}

\section{BSRA}

In the immediate post-1945 period a great deal of BSRA extra mural research was undertaken on hydrodynamics, concentrating on the need to determine more accurately the resistance to be overcome in propelling a ship through water. By March 1949, BSRA had issued twenty-one research reports and four Technical Memoranda to member firms. Thereafter, the annual output of research reports settled to around twenty-three. However, the BSRA Council noted that the distribution of these reports among the technical staffs of member firms was not wide enough and suggested that senior staff should visit member firms at least once a year to discuss the reports that had been issued. Such personal contacts would have the added benefit in assisting BSRA to determine the best method in disseminating the results of its research and would further encourage member firms to submit research enquiries. ${ }^{58}$

By September 1953, the BSRA staff had increased to eighty, of whom thirtythree were graduates or their equivalent (five years earlier the numbers were sixtyfive and twenty-six respectively). The forty-seven non-graduate staff included seven in the Drawing Office, two in computing, four instrument makers and one instrument case maker in a small laboratory at Palmer's Hill, Sunderland made available to BSRA by Doxford. The remaining thirty-three employees were involved in administrative and clerical tasks. ${ }^{59}$

Expenditure of BSRA in the year 1949-50 had been $£ 127,000$ out of a total income received of $£ 193,326$. By 1953 , expenditure had risen to an estimated $£ 194,000$ out of a total income received of $£ 243,000$. The jump in expenditure had an impact on the build-up of reserves for BSRA. Earlier, the impact on expenditure was in fact quicker than anticipated largely due to heavy extra mural costs on BSRA full-scale experiments on the resistance of a ship's hull with the sixty-two-

\footnotetext{
56 Storey and Crowdy, "Final years of Doxford," 66.

57 Respectively, MV Egori built by Scott's Shipbuilding and Engineering Co., Ltd, Greenock for Elder Dempster Line, Liverpool, MT Spinanger built by Sir James Laing, Deptford, Sunderland for Ropner Shipping, Hartlepool, MT Thirlby built by J.L. Thompson, Sunderland for Westfal-Larsen, Bergen.

58 BSRA $^{\text {th }}$ Report 1 April 1948 to 31 March 1950, author's copy.

59 BSRA $8^{\mathrm{TH}}$ Report, 1 April 1953 to 31 March 1954, author's copy.
} 
years old Clyde paddle steamer, Lucy Ashton in the years 1950 and $1951 .^{60}$ This was an important series of experiments in the history of naval architecture. ${ }^{61}$ The establishment of BSRA eventually gave rise to similar organisations in major shipbuilding countries, and between 1947 and 1955 national shipbuilding research associations had been formed in Belgium, France, Holland, Japan, Norway and Sweden. ${ }^{62}$

Clearly, year-on-year rises in expenditure due to extra mural costs would have an impact on BSRAs viability, and by 1954 it was settled policy through the Shipbuilding Conference and indeed the DSIR, in line with the latter's general policy on research organizations, to build up BSRA reserves to ensure a surplus of income over foreseeable expenditure. Conference policy was to build-up BSRA reserves to the equivalent of two years' normal expenditure with the anticipation that the reserve would stand at $£ 400,000$ in March $1954 .{ }^{63}$

Breaking down the four major areas of BSRA research expenditure at March 1953 in terms of direct costs and associated overheads, under the headingHydrodynamics: resistance and hull form took up 10.4 percent, and propulsion 0.9 percent. Ships Machinery accounted for 40.8 percent with the major item being research into the internal combustion engine. Ships Performance took 7.2 percent and Ships Structures 16.9 percent. Overall, BSRA could charge direct to particular items of work 70 percent of its total expenditure, with just over 80 percent of the association's resources devoted to work upon items of its research program. ${ }^{64}$

By this stage, BSRA had submitted an estimate for financial expenditure for the five years 1954/55 to $1958 / 59$ ranging from $£ 198,000$ to $£ 213,500$ per annum. However, it was not possible to estimate the amount of DSIR grants, beyond the likely enforcement of DSIR policy to curtail basic grants to industrial research associations, and to lower maximum grants by relating them somewhat differently to the direct contributions made by industry. In this DSIR was following not

${ }^{60}$ Report of the AGM of the Shipbuilding Conference, 5 March 1952, NMM SRNA 7. The Conference agreed to increase BSRA's grant for the year ending 31 March 1952 from $£ 100,000$ to $£ 120,000$ re the additional special expenditure on the Lucy Ashton.

${ }^{61}$ The 271-ton paddle steamer Lucy Ashton was launched from the Rutherglen shipyard of W.B. Staith on 24 May 1888 and for the most part plied her trade on the Gareloch until being sent to the shipbreakers in 1949. The novel idea of propelling Lucy Ashton through the water with externally mounted aero jet engines [Rolls Royce Derwent V] was undertaken by BSRA. The ship was stripped of her own machinery, paddle wheels and deck houses; and a gantry carrying four second-hand aero engines was mounted across the ship. A cine-theodolite camera was used to determine very accurately the timing of the passing of the measured mile posts on the shore of the Gareloch from which the ship's speed was calculated. See, Sir Maurice E. Denny, "BSRA Resistance Experiments on the Lucy Ashton," Transactions of the Institute of Naval Architects, 1951.

62 Dr S. Livingston Smith, Paper read to the Summer Meeting of the Institute of Naval Architects, Paris, 1 July 1958, 3. Sweden established a Shipbuilding Research Foundation in April 1955, see, L.O. Olsen, Technology Carriers. The Role of Engineers in the Expanding Swedish Shipbuilding System (Gothenburg: Chalmers University of Technology, 2000),181-193.

${ }_{63}$ Report of the AGM of the Shipbuilding Conference, 9 October 1952, NMM SRNA 7.

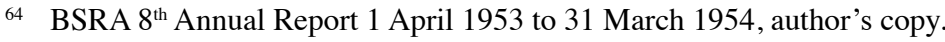


unreasonable and longstanding government policy that once research associations had become established then industry contributions to them should be increased with a commensurate decrease in DSIR funding. Therefore, if expenditure was to continue at the current rate then the industry would have to increase its contribution or BSRA would have to draw upon its extant reserves, or a combination of the two. Accordingly, the Conference voted to continue funding BSRA to enable the latter's research expenditure to continue at current levels for five years from 1 April 1954 to 31 March 1959 with the caveat added, "so long as the state of the industry permits." $" 65$

An important event transpired in October 1957 when the BSRA Council finally implemented associate membership for shipowners ${ }^{66}$ By December 1957 , BSRA had issued 227 research reports to members and seventy-two papers had been read on its behalf to various associations and societies, and no major changes had been made in its function or organisation. ${ }^{67}$ BSRA's extra mural experiments in hydrodynamics were further aided by a series of new test tanks, including one outdoor tank at the NPL's new facility at Feltham, Middlesex, opened in October 1959.68

\section{PAMETRADA}

With work continuing in testing the Daring Class turbine machinery, in 1951 a founding member firm, C.A. Parsons resigned its membership of PAMETRADA. Despite this, the name of the association was retained, when it would have been undoubtedly better advised to rename and refocus its activities. During 1951 and 1952, one Canadian and five Dutch turbine builders were accepted as licencees. ${ }^{69}$ Work continued on the experimental gas turbine program at Wallsend. The small proportion of a warship's life steaming at near or full power made the gas turbine boost principle an attractive proposition, particularly at short notice. However, PAMETRADA gas turbine research illustrated the problems of industrial research in general in that it was generally a process of trial and error, fault finding, rectification and solution, and given this, financial forecasting re expenditures was hazardous if something went fundamentally wrong, or a process took far longer than originally anticipated.

Earlier in November 1950, there had been an approach to the Shipbuilding Conference by its members' Warship Group in seeking a grant toward funding for PAMETRADA. It later transpired that original estimates on the experimental turbine unit had been substantially exceeded owing to rapidly increasing labour and material costs, and the need for additional equipment to prosecute research.

\footnotetext{
65 Report of the AGM of the Shipbuilding Conference, 7 October 1953, and 14 October 1954, NMM SRNA 7.

66 Extract from AGM 9 October 1957, NMM SRNA R4/17.

67 Livingston Smith paper, 1 July 1958, 1.

68 No.3 Test tank there was 400 metres long.

69 Darling, 40 Years of Progress, 30.
} 


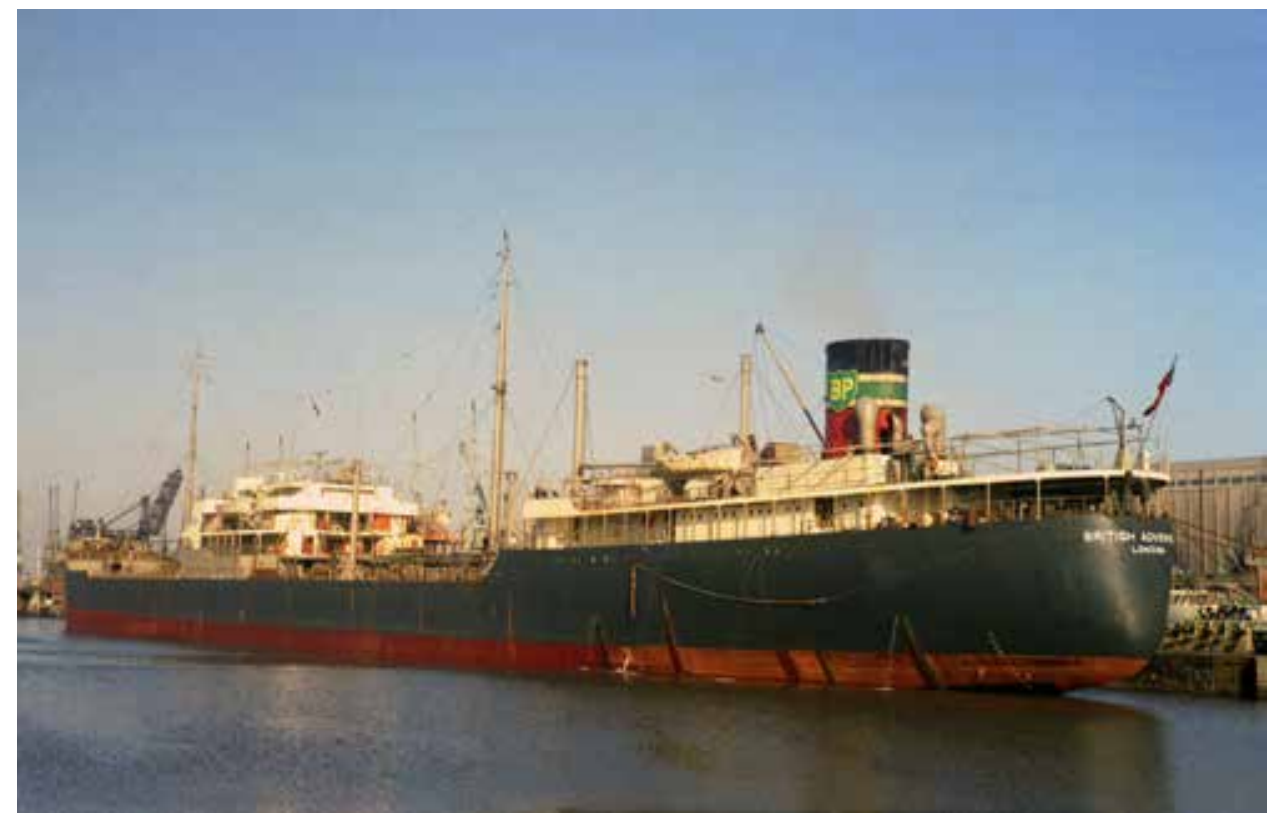

British Adventure (Shipspottingcom)

Subsequently the Shipbuilding Conference agreed to grant PAMETRADA $£ 50,000$ in the 1950-1951 financial year with the possibility of a further grant in 1952 and noted that steps had been taken to reorganise it along the lines of BSRA by instituting a research council and research board, and an administration and finance committee. ${ }^{70}$

As a quid pro quo, the Conference insisted on representation on two of PAMETRADA's research and finance committees, which was granted by May 1951. PAMETRADA also agreed to appoint a small committee to investigate liaison arrangements and collaboration with the work of BSRA..$^{71}$ Subsequently the grant to PAMETRADA of $£ 50,000$ mooted for 1952 was agreed by the Shipbuilding Conference, making the latter's contribution to PAMETRADA thus far, $£ 100,000 .^{72}$

Contemporaneously, the tankers, British Adventure and British Bulldog went into service equipped with PAMETRADA's standard design of compound machinery with all-impulse H.P. turbines, and the Anglo-Saxon Petroleum Company decided to fit PAMETRADA machinery of 7,500 shp in their 18,000 dwt

\footnotetext{
70 Report of Meeting of Executive Board of the Shipbuilding Conference, 7 March 1951, NMM SRNA 7.

71 Report of a Meeting of Executive Board of the Shipbuilding Conference, 8 May 1951, NMM SRNA 7.

72 Report of AGM of Shipbuilding Conference, 5 March 1952, NMM SRNA 7.
} 
tankers, sixty of which were on order, a significant event to its future prospects. ${ }^{73}$

Discussions were entered with PAMETRADA re Boost Gas Turbines for General Purpose Frigates and Guided Missile Destroyers in 1952, for PAMETRADA to investigate the possibility of designing the main steam turbine in conjunction with the Metropolitan-Vickers gas turbine. The latter were however only prepared to go forward provided they designed and built the prototype machinery, both steam and gas turbines plus gearing. Subsequently, a Mr N. Elce of Metropolitan Vickers intimated that his firm "had no desire to make further entries into the marine field." 74

In 1953, PAMETRADA, cogniscent on the withdrawal of Admiralty support on continuing gas turbine research for naval purposes in design and testing, announced that it was ready to accept orders for gas turbine installations for commercial vessels, and that "such a set could be designed and constructed for a service of at least 100,000 hours at full power, corresponding to at least 20 years' service." 75 This announcement proved to be premature as the experimental gas turbine was subsequently out of action for the whole of the year 1954, following an explosion where it had its blading stripped during fuel tests in December 1953, whose cause was unknown. ${ }^{76} \mathrm{Up}$ to that stage, PAMETRADA had made some progress on the means of overcoming corrosion and fouling problems which impeded the development of marine turbines of greater efficiency, but ultimately the cost of an additive to residual fuel proved commercially unviable. ${ }^{77}$

By 1953, however, it should have become abundantly clear to PAMETRADA that the Royal Navy preferred the land turbine sector for design and manufacture of turbines of higher powers. During the year PAMETRADA submitted a design for a 45,000 shp turbine for a projected aircraft carrier. During discussion of the design, which was somewhat unorthodox, the navy's Engineer in Chief, intimated that he had insufficient confidence, in PAMETRADA design staff to recommend the design to the [Admiralty] Board for installation in a Ship without the advice of an outside consultant. He further stated that there was some question of obtaining design information on a US Navy carrier turbine design. Unsurprisingly, English Electric were asked in July to produce the design to keep their design team together. ${ }^{78}$

PAMETRADA's design department published charts in 1955 showing that in its first decade of operation weights of turbines and gearing had been reduced by over 50 percent and fuel consumption by 11 percent, with aggregate horsepower of

\footnotetext{
Darling, Forty years of progress, 46.

74 Memorandum on Pametrada, 16 July 1965, TNA BT186/20 SIC Evidence.

75 The Motor Ship, "Pametrada Marine Gas Turbine," November 1953.

76 The Motor Ship, "Pametrada Gas Turbine Research," August 1955, and "Gas Turbine Developments," September 1955.

77 As did the necessity of drying the gas oil, which is added to prevent the deposit of silica. The Motor Ship, February 1954.

78 Memorandum on Pametrada, 16 July 1965, TNA BT186/20 SIC Evidence.
} 
ships in service over the period at $2.5 \mathrm{~m} \mathrm{hp}$ and rising by $500,000 \mathrm{hp}$ per annum. ${ }^{79}$ This, at least, pointed to progress in design on the back of continuous testing of marine turbines for mercantile use.

Ultimately, however, the principal demand for UK manufactured steam turbines remained with UK shipowners who built in the domestic shipbuilding industry, and the Admiralty who ordered warships for the Royal Navy. On the mercantile side, the possibility of direct exports, limited by Licence restrictions, but essentially limited because of overseas domestic builders supplying their own shipbuilding industries, meant that the future of these manufactures was primarily linked to that of the British shipbuilding industry. Moreover, gas turbines were primarily attractive to navies, and the land turbine firms such as AEI (who had subsumed the brand names British Thomson Houston and Metropolitan Vickers under the AEI brand in 1959) and English Electric, had more financial resources to exploit this market.

On the mercantile side, despite PAMETRADA research efforts, gas turbines had little appeal. Given, at this stage of their development, high fuel consumption, difficulties to scaling of turbine blades, and the necessity to employ bulky, complex and expensive heat exchanger equipment, their use in merchant vessels was unviable.

Indeed, the effect of Admiralty withdrawal from testing at PAMETRADA meant that the latter's major research focus applied to improving its own designs for licencees. This implied a greater level of expenditure to keep up with rapidly changing developments, however, the focus, despite the considerable amount of research on liquid cooled gas turbines, which was slowed down "solely due to the need to conserve financial resources after Admiralty support was withdrawn," remained on steam turbines. ${ }^{80}$

By this stage, the long post-war seller's market in shipbuilding had ended, and the British shipbuilding industry was under serious competitive pressure in the international market for ships. Not only had Japan overtook Britain's shipbuilding industry in 1956 as the world's largest producer, the industry was also under increasing competitive pressure from West Germany and Sweden. Clearly, with international competition making substantial inroads, the Shipbuilding Conference were now much more clearly focussed on value for money in research. Moreover, so was the State in the shape of the DISR who, over the decade 1950-51 to 1959-60 had sanctioned grants to BSRA and PAMETRADA totalling $£ 1,344,900$. Over the same period, NPL expenditure amounted to $£ 811,900 .{ }^{81}$

Against the real prospect of an enduring depression in British shipbuilding from 1958 onwards and the effects on its international competitive position, some form of government action was deemed necessary. A starting point was yet another

\footnotetext{
79 Darling, Forty years of progress, 46.

80 Note on Pametrada, undated, NMM, SRNA R18/2.

81 The Motor Ship, "British Shipbuilding Today," 1966, 85.
} 
enquiry. Before discussing this, it is important to examine the context in which BSRA and PAMETRADA operated.

\section{The general situation in shipbuilding 1950 to 1965}

The starting point for many post hoc judgements is that victory in the Second World War should have given Britain a marked competitive advantage over her major pre-war competitors, Germany and Japan, whose shipbuilding industries suffered considerable damage. However, throughout the 1950s, that Britain, alone of all the major shipbuilding nations not only lost market share but also failed to expand its absolute level of output is well known. Thereafter, British shipbuilders overall capacity to build, and projections for orders and growth was indelibly linked to the replacement and new tonnage requirements of its mercantile marine. For decades this had been a symbiotic relationship, an attempt to balance demand and supply in equilibrium, which hitherto had ushered in British shipbuilding supremacy. ${ }^{82}$

From 1948 to 1965 the world merchant fleet grew from 29,340 vessels totalling $80,291,593 \mathrm{grt}$ to 41,865 vessels totalling $160,391,504 \mathrm{grt}$. In the same period world shipbuilding launches increased from 2,093,00grt to 12,216,000grt. As the world fleet doubled, Britain's grew only by 16 percent, and the percentage of the world's fleet comprising British ships fell from 24 percent to 13 percent . In 1948 British shipbuilding firms launched 342 vessels totalling 1,176,112 grt, 55 percent of total world output, but by 1965 , launches had fallen to 158 vessels totalling $1,073,074$ grt, eight percent of world output. ${ }^{83}$

That this transpired during the Long Boom in international trade, is doubly perplexing. Whilst realising that any discussion of relative decline necessarily involves a full discussion of a myriad of internal and external factors including technical change within the industry, or the response to technical change by competitor countries, the propensity elsewhere, particularly Japan and Sweden for tankers and dry bulk carriers of rapidly increasing size, a market British shipbuilding largely missed out on, indicated a very real loss of international competitiveness even when the level of national shipbuilding output was more or less constant. As Catherwood has noted, a declining volume of output with an increasing national share is normally a healthier sign than an increasing volume and declining market share, more so in the latter case in any subsequent downturn

\footnotetext{
82 The importance of the 1950s, particularly the commercially crucial years 1951-54 is highlighted in Corelli Barnett, The Audit of War: The Illusion and Reality of Britain as a Great Nation (London: Macmillan, 1986),123, Edward H. Lorenz, Economic Decline in Britain: The Shipbuilding Industry, 1890-1970 (Oxford: Oxford University Press,1991),132-136 identifies the 1950s as the key turning point in the industry's fortunes but left its significance to future research. Their points are discussed in detail by H. Murphy, "No longer competitive with Continental Shipbuilders. British Shipbuilding and International Competition, 1930-1966," International Journal of Maritime History, 25: 2, (2013), 35-60.

83 All figures are either from or derived from Lloyds Register of Shipping, Annual Summaries.
} 
in the trade cycle. ${ }^{84}$ Table I below gives growth rates from 1955 to 1971 of seven leading shipbuilding nations.

Table I: Growth in output (grt) of leading shipbuilding countries, 1955-1971

Country Growth rate 1955-1971 (\%)

\begin{tabular}{lr}
\hline Japan & 20.5 \\
Spain & 18.9 \\
Norway & 11.8 \\
Sweden & 8.4 \\
France & 6.9 \\
West Germany & 4.5 \\
United Kingdom & 0.0
\end{tabular}

Source: British Shipbuilding 1972. A Report to the Department of Trade and Industry by Booz, Allen and Hamilton International BV, (London: HMSO, 1973), 90.

From 1955 to 1971, UK shipbuilding output had remained static at an average annual output of approximately $1.2 \mathrm{mgrt}$ per annum, and the UK share of the world market declined from 27 percent to 5 percent. In stark contrast, over the same period, Japan's share increased from 11 percent to 46 percent, and Norway and Spain both increased their shares of output. West Germany, France and Sweden all suffered reductions in market share, but tellingly, the UK shipbuilding industry experienced no growth whatsoever in the 16-year period. A sorry situation that would worsen further up to 1977 when the industry was nationalised.

Up to 1965 , the UK share of the world shipbuilding export market also plummeted, laying bare the industry's lack of international competitiveness. Britain had 35 percent of the world export market in 1948-50 but by 1965 this had plummeted to 4.5 percent. Commensurately, Japan's share had over the same period rose from 2 percent to 39 percent . From the end of the 1950s, British shipowners had begun to desert the industry for countries offering lower prices and quicker deliveries. Indeed, by the end of the decade, 23 percent of ships for UK registration were built abroad. Compounding shipbuilding and marine engine building's difficulties, a severe slump in freight rates occurred in 1957, and by 1959, 9 mgrt of shipping was laid up. This obviously had a lag effect that impacted on shipbuilding and future main engine orders. With a declining domestic market and a rapidly decreasing export market the industry's strategy of balancing demand and supply was under serious pressure, a trend which grew substantially throughout the 1960 s, as the following table illustrates.

${ }^{84}$ H.F.R. Catherwood, Britain with the Brakes Off (London: Hodder \& Stoughton, 1966), 74. 
Table II: Ships delivered to the UK Registered Fleet, 1948-1970

\begin{tabular}{lrr} 
Years & \multicolumn{2}{c}{$\begin{array}{r}\text { Percent from UK and Foreign Yards } \\
\text { UK }\end{array}$} \\
$1948-50$ & 100.0 & Foreign \\
$1951-55$ & 96.8 & 0.0 \\
$1956-60$ & 81.1 & 3.2 \\
$1961-65$ & 61.7 & 19.9 \\
$1966-70$ & 26.0 & 38.3 \\
& & 74.0
\end{tabular}

Source: Lloyd's Register of Shipping

These levels of desertion by British shipowners had severe repercussions for shipbuilding and main engine manufacture and entailed that some form of rationalisation of firms in these sectors would inevitably take place as market shares shrank. Against this backdrop, government, increasingly frustrated by the industry's relative decline, sought answers to address its lack of competitiveness.

$\mathrm{Nb}$. Part III follows in the next issue. 